\title{
Direct modulation of basal and angiotensin II-stimulated aldosterone secretion by hydrogen ions
}

\author{
R E Kramer, T V Robinson ${ }^{1}$, E G Schneider ${ }^{1}$ and T G Smith \\ Department of Pharmacology and Toxicology, University of Mississippi Medical Center, Jackson, Mississippi 39216, USA \\ ${ }^{1}$ Department of Physiology and Biophysics, University of Tennessee, Memphis, Tennessee 38163, USA \\ (Requests for offprints should be addressed to R E Kramer, Department of Pharmacology and Toxicology, University of Mississippi Medical Center, \\ 2500 North State Street, Jackson, Mississippi 39216-4505, USA; Email: rkramer@pharmacology.umsmed.edu)
}

\begin{abstract}
Disturbances in acid-base balance in vivo are associated with changes in plasma aldosterone concentration, and in vitro changes in extracellular $\mathrm{pH}\left(\mathrm{pH}_{\mathrm{o}}\right)$ influence the secretion of aldosterone by adrenocortical tissue or glomerulosa cells. There is considerable disparity, however, as to the direction of the effect. Furthermore, the mechanisms by which $\mathrm{pH}_{\mathrm{o}}$ independently affects aldosterone secretion or interacts with other secretagogues are not defined. Thus, bovine glomerulosa cells maintained in primary monolayer culture were used to examine the direct effects of $\mathrm{pH}_{\mathrm{o}}$ on cytosolic free calcium concentration $\left(\left[\mathrm{Ca}^{2+}\right]_{\mathrm{i}}\right)$ and aldosterone secretion under basal and angiotensin II (AngII)-stimulated conditions. $\mathrm{pH}_{\mathrm{o}}$ was varied from $7 \cdot 0$ to $7 \cdot 8$ (corresponding inversely to changes in extracellular $\mathrm{H}^{+}$concentration from $16 \mathrm{nM}$ to $100 \mathrm{nM}$ ). Whereas an elevation of $\mathrm{pH}_{\mathrm{o}}$ from $7 \cdot 4$ to $7 \cdot 8$ had no consistent effect, reductions of $\mathrm{pH}_{\mathrm{o}}$ from $7 \cdot 4$ to $7 \cdot 2$ or 7.0 caused proportionate increases in aldosterone secretion that were accompanied by increases in transmembrane $\mathrm{Ca}^{2+}$ fluxes and $\left[\mathrm{Ca}^{2+}\right]_{\mathrm{i}}$. These effects were abolished by removal of extracellular $\mathrm{Ca}^{2+}$. A decrease in
\end{abstract}

$\mathrm{pH}_{\mathrm{o}}$ from $7 \cdot 4$ to $7 \cdot 0$ also enhanced AngII-stimulated aldosterone secretion. This effect was more pronounced at low concentrations of AngII and was manifested as an increase in the magnitude of the secretory response with no effect on potency. In contrast to its effect on AngIIstimulated aldosterone secretion, a reduction of $\mathrm{pH}_{\mathrm{o}}$ from $7 \cdot 4$ to $7 \cdot 0$ inhibited the $\mathrm{Ca}^{2+}$ signal elicited by low concentrations $\left(\leq 1 \times 10^{-10} \mathrm{M}\right)$ of AngII, but did not affect the increase in $\left[\mathrm{Ca}^{2+}\right]_{\mathrm{i}}$ caused by a maximal concentration $\left(1 \times 10^{-8} \mathrm{M}\right)$ of AngII. These data suggest that $\mathrm{pH}_{\mathrm{o}}$ (i.e. $\mathrm{H}^{+}$) has multiple effects on aldosterone secretion. It independently increases aldosterone secretion through a mechanism involving $\mathrm{Ca}^{2+}$ influx and an increase in $\left[\mathrm{Ca}^{2+}\right]_{\mathrm{i}}$. Also, it modulates the action of AngII by both decreasing the magnitude of the AngII-stimulated $\mathrm{Ca}^{2+}$ signal and increasing the sensitivity of a more distal site to intracellular $\mathrm{Ca}^{2+}$. The latter action appears to be a more important determinant in the effects of $\mathrm{pH}_{\mathrm{o}}$ on AngII-stimulated aldosterone secretion.

Journal of Endocrinology (2000) 166, 183-194

\section{Introduction}

Plasma aldosterone concentration is known to change in response to alterations in acid-base balance. For example, aldosterone levels in plasma increased during diabetic ketoacidosis (Christlieb et al. 1975, Scott et al. 1978, Quigley et al. 1982), metabolic acidosis (Perez et al. 1977, 1979, 1980, Schambelan \& Sebastian 1977) and acute respiratory acidosis (Raff \& Roarty 1988). Conversely, during metabolic alkalosis (Kassirer et al. 1967, Julian et al. 1982), plasma aldosterone concentration decreased. Interpretation of these effects, however, is complicated by concurrent changes in plasma renin activity, plasma $\mathrm{K}^{+}$ concentration and/or plasma adrenocorticotropin (ACTH) concentration - parameters that in and of themselves are important determinants of aldosterone secretion.
The possibility that alterations in extracellular $\mathrm{pH}\left(\mathrm{pH}_{\mathrm{o}}\right)$ directly affect the rate of aldosterone secretion has been examined under a variety of experimental conditions both in vivo (Jones et al. 1992, Yamauchi et al. 1997) and in vitro (Muller 1965, Chiu \& Freer 1979, Gilchrist et al. 1983, Carroll et al. 1986, Radke et al. 1986a,b, Raff \& Jankowski 1993). Although results of these studies generally support that premise, data concerning the specific nature of the effect are contradictory and interpretation of the results is complicated by a number of confounding variables. The possibility that indirect actions of $\mathrm{H}^{+}$(i.e. $\mathrm{pH}_{\mathrm{o}}$ ) contributed to its effects on aldosterone secretion by intact adrenal glands or adrenal sections can not be entirely excluded. In addition, there were considerable differences between the magnitudes of the changes in $\mathrm{pH}_{\mathrm{o}}$. Such differences may well contribute to disparities between the 
apparent relationship between $\mathrm{pH}_{\mathrm{o}}$ and aldosterone secretion. In some cases, the magnitudes of the changes in $\mathrm{pH}_{\mathrm{o}}$ were such that the physiological relevance of the results is unclear. Also, differences in the means by which $\mathrm{pH}_{\mathrm{o}}$ was altered may influence the rapidity and extent of compensation by the glomerulosa cells and, ultimately, aldosterone secretion.

The first objective of the present studies was to determine, using primary cultures of bovine glomerulosa cells as an experimental model, if changes in extracellular $\mathrm{H}^{+}$ concentration $\left(\left[\mathrm{H}^{+}\right]_{\mathrm{o}}\right)$ comparable to those that occur in vivo under physiological and pathophysiological conditions affect aldosterone secretion directly. The second objective was to determine if any direct steroidogenic effect of $\mathrm{H}^{+}$ was associated with changes in cell $\mathrm{Ca}^{2+}$. Changes in $\left[\mathrm{H}^{+}\right]_{\mathrm{o}}$ over the range of 16 to $100 \mathrm{nM}\left(\mathrm{pH}_{\mathrm{o}} 7 \cdot 8\right.$ to $7 \cdot 0$ respectively) were related to changes in transmembrane $\mathrm{Ca}^{2+}$ fluxes, cytosolic free calcium concentration $\left(\left[\mathrm{Ca}^{2+}\right]_{\mathrm{i}}\right)$ and aldosterone secretion. Finally, the ability of $\mathrm{H}^{+}$to modulate the $\mathrm{Ca}^{2+}$ signal and the aldosterone secretory response elicited by angiotensin II (AngII) was examined. The results indicate that $\mathrm{H}^{+}$has a direct action on glomerulosa cells to stimulate aldosterone secretion through a mechanism involving an increase in $\left[\mathrm{Ca}^{2+}\right]_{\mathrm{i}} . \mathrm{H}^{+}$ also directly enhanced the secretory response to AngII, but this effect was dissociated from those of $\mathrm{H}^{+}$on AngII-stimulated increases in $\left[\mathrm{Ca}^{2+}\right]_{\mathrm{i}}$. Results of these investigations have been reported, in part, in an earlier communication (Robinson et al. 1990).

\section{Materials and Methods}

\section{Cell culture}

Glomerulosa cells were isolated from bovine adrenal glands and suspended in a modified Ham's F-12 medium containing horse serum $(10 \% \mathrm{v} / \mathrm{v})$ and Hepes $(25 \mathrm{mM}$, pH 7·4 at $37^{\circ} \mathrm{C}$ ) buffer as previously described (Kramer 1988a). Cells were seeded to either Leighton tubes containing a fibronectin-coated $\left(2 \mu \mathrm{g} / \mathrm{cm}^{2}\right) 9 \times 35 \mathrm{~mm}$ glass coverslip or fibronectin-coated cell culture dishes. Medium was changed 16-20 h after seeding and then at $48 \mathrm{~h}$ intervals. Cells achieved confluence within 5-7 days and were then maintained for an additional 24-96 h in serum-free Ham's F12/Hepes medium. Subsequent experiments were performed using Hanks' balanced salt solution (HBSS) modified to contain $0.2 \mathrm{mg} / \mathrm{ml} \mathrm{BSA}, 4 \mathrm{mM} \mathrm{KCl}, 1.8 \mathrm{mM}$ $\mathrm{CaCl}_{2}, 4 \mathrm{mM} \mathrm{NaHCO}_{3}$ and $10 \mathrm{mM}$ Hepes buffer $(\mathrm{pH} 7 \cdot 4$ at $37^{\circ} \mathrm{C}$ ).

$\mathrm{Ca}^{2+}$ fluxes and $\left[\mathrm{Ca}^{2+}\right]_{i}$

$\left[\mathrm{Ca}^{2+}\right]_{\mathrm{i}}$ was estimated from the ratio of fura 2 fluorescences (emission $510 \mathrm{~nm}$ ) when excited alternately at 340 and $380 \mathrm{~nm}$ (Grynkiewicz et al. 1985) after correction for cell autofluorescences. Monolayers adhering to glass coverslips were incubated in the presence of $2 \mu \mathrm{M}$ fura 2 AM for 45-60 min. Then, fura2 fluorescences were monitored continuously as the cells were superfused with HBSS/ Hepes buffer ( $\mathrm{pH} 7 \cdot 4$ at $37^{\circ} \mathrm{C}$ ) at a rate of approximately $3 \mathrm{ml} / \mathrm{min}$ (Kramer 1991). The temperature of the superfusate within the cell chamber varied between 36 and $37.5{ }^{\circ} \mathrm{C}$. The composition and/or $\mathrm{pH}$ of the superfusate was changed as indicated for specific experiments after steady-state basal data had been collected for at least $15 \mathrm{~min}$. Alterations in $\mathrm{pH}_{\mathrm{o}}$ over the range used in these experiments affected calibration parameters used in the calculation of $\left[\mathrm{Ca}^{2+}\right]_{i}$ by less than $5 \%$. These effects were ignored, since cytosolic $\mathrm{pH}\left(\mathrm{pH}_{\mathrm{i}}\right)$ changed over a narrower range $(\sim 7 \cdot 05-7 \cdot 30)$ than did $\mathrm{pH}_{\mathrm{o}}$. Calibration parameters were determined as described previously (Tsien et al. 1985).

To allow measurement of $\mathrm{Ca}^{2+}$ efflux, cells adhering to glass coverslips were incubated in the presence of $10 \mu \mathrm{Ci}$ $\left[{ }^{45} \mathrm{Ca}\right] \mathrm{CaCl}_{2}$ for $2 \mathrm{~h}$. In experiments in which ${ }^{45} \mathrm{Ca}^{2+}$ efflux and $\left[\mathrm{Ca}^{2+}\right]_{\mathrm{i}}$ were measured simultaneously, $2 \mu \mathrm{M}$ fura2 AM was also present during the second hour of incubation. Cells were then subjected to superfusion, and the superfusate was collected in $1 \mathrm{~min}$ fractions. The ${ }^{45} \mathrm{Ca}^{2+}$ content of each fraction and the amount of ${ }^{45} \mathrm{Ca}^{2+}$ remaining in the cells at the end of the experimental protocol were determined by liquid scintillation counting (Kramer 1988b). Calcium efflux during each $1 \mathrm{~min}$ interval is expressed as a percentage of the total ${ }^{45} \mathrm{Ca}^{2+}$ contained within the cells at the beginning of that interval, i.e. as the $\mathrm{Ca}^{2+}$ efflux coefficient (Borle et al. 1982).

For the measurement of $\mathrm{Ca}^{2+}$ uptake, monolayers in $60 \mathrm{~mm}$ dishes or six-well clusters were first incubated in HBSS/Hepes buffer ( $\mathrm{pH} 7 \cdot 4$ at $37^{\circ} \mathrm{C}$ ) for 60 min. Next, buffer was replaced with $2 \mathrm{ml}$ HBSS/Hepes buffer of appropriate $\mathrm{pH}(7 \cdot 8,7 \cdot 4$ or $7 \cdot 0)$ containing $2 \mu \mathrm{Ci}$ $\left[{ }^{45} \mathrm{Ca}\right] \mathrm{CaCl}_{2}$. Accumulation of ${ }^{45} \mathrm{Ca}^{2+}$ was terminated 10 , $20,30,60$ or $120 \mathrm{~s}$ thereafter, by the addition of an equal volume of cold $2 \times$ stop solution $\left(20 \mathrm{mM} \mathrm{LaCl}_{3} / 200 \mathrm{mM}\right.$ $\left.\mathrm{Mg}\left(\mathrm{C}_{2} \mathrm{H}_{3} \mathrm{O}_{2}\right)_{2} \cdot 4 \mathrm{H}_{2} \mathrm{O} \quad \mathrm{pH} \quad 6 \cdot 0\right)$. This solution was aspirated, and the cells were rinsed three times with $10 \mathrm{ml}$ cold $1 \times$ stop solution. Zero-time samples were prepared by adding $2 \mathrm{ml} 2 \times$ stop solution to the cells prior to addition of $2 \mathrm{ml} \mathrm{HBSS} /$ Hepes buffer containing $\left[{ }^{45} \mathrm{Ca}\right] \mathrm{CaCl}_{2}$. Cells were lysed in $0 \cdot 1 \mathrm{M}$ nitric acid, and isotopic $\mathrm{Ca}^{2+}$ contents of the cell lysates were measured by liquid scintillation counting. Residual cell protein was rinsed with saline and then dissolved in $0.5 \mathrm{M} \mathrm{NaOH}$ for quantitation.

\section{Aldosterone secretion}

Cells previously grown to confluence in 48-well cluster dishes and maintained in serum-free Ham's F12 medium were incubated for $60 \mathrm{~min}$ in HBSS/Hepes buffer ( $\mathrm{pH} 7 \cdot 4$ at $37^{\circ} \mathrm{C}$ ) containing $2 \mathrm{mg} / \mathrm{ml} \mathrm{BSA}$ and then for an 
additional $60 \mathrm{~min}$ in buffer containing $0.2 \mathrm{mg} / \mathrm{ml} \mathrm{BSA}$. In experiments in which the effects of $\mathrm{H}^{+}$alone were examined, cells were incubated for $120 \mathrm{~min}$ in fresh buffer that had been adjusted to $\mathrm{pH} 7 \cdot 0,7 \cdot 2,7 \cdot 4$ or $7 \cdot 8$. In experiments in which the interaction between $\mathrm{H}^{+}$and AngII was examined, cells were incubated first for $15 \mathrm{~min}$ in buffer of the indicated $\mathrm{pH}$ and then for $120 \mathrm{~min}$ after addition of AngII $\left(1 \times 10^{-12}\right.$ to $\left.1 \times 10^{-8} \mathrm{M}\right)$. Parallel incubations were ended at either 15 or $135 \mathrm{~min}$. Media were collected, stored at $-20^{\circ} \mathrm{C}$ and later used for the measurement of aldosterone. Cells were rinsed twice with saline, and total cell protein was measured against BSA standards using a bicinchoninic acid-based assay (Pierce, Rockford, IL, USA) after lysis of the cells in $0.5 \mathrm{M}$ $\mathrm{NaOH}$. Aldosterone contents of the incubation media were measured by direct RIA using ${ }^{125}$ I-aldosterone and aldosterone antibody-coated tubes (Diagnostic Products, Los Angeles, CA, USA).

\section{Specific reagents and buffers}

Ham's F12 medium, HBSS, horse serum and antibiotics were obtained from Gibco (Grand Island, NY, USA), and other components of the media and buffers were from Sigma (St Louis, MO, USA). Dispase and collagenase were from Boehringer Mannheim (Indianapolis, IN, USA), and plastic culture dishes were from Co-Star (Cambridge, MA, USA). Fura2 and fura2 AM were obtained from Molecular Probes (Eugene, OR, USA). Isotopic $\mathrm{Ca}^{2+}$ was purchased from New England Nuclear (Boston, MA, USA), and AngII, [ $\left.{ }^{5} \mathrm{Val}\right]$ AngII, was purchased from Bachem Inc. (Torrence, CA, USA).

Modified HBSS/Hepes buffers used for superfusion and static incubations were prepared as follows. A control buffer of $\mathrm{pH} 7.4$ at $37^{\circ} \mathrm{C}$ was prepared that contained $4 \mathrm{mM} \mathrm{KCl}, 1 \mathrm{mM} \mathrm{MgSO} 4,1.8 \mathrm{mM} \mathrm{CaCl}, 0.44 \mathrm{mM}$ $\mathrm{NaH}_{2} \mathrm{PO}_{4}, \quad 0.34 \mathrm{mM} \quad \mathrm{Na}_{2} \mathrm{HPO}_{4}, \quad 4 \mathrm{mM} \mathrm{NaHCO}_{3}$, $10 \mathrm{mM}$ Hepes, $5 \cdot 6 \mathrm{mM}$ glucose, $0 \cdot 2 \mathrm{mg} / \mathrm{ml} \mathrm{BSA}$, and a $\left[\mathrm{Na}^{+}\right]$from the addition of both $\mathrm{NaOH}$ and $\mathrm{NaCl}$ of $137 \mathrm{mM}$. The final $\left[\mathrm{Na}^{+}\right]$was approximately $142 \mathrm{mM}$, and the final osmolality was $278 \pm 1$ mosmol. Aliquots of the control buffer were removed, and the $\mathrm{pH}$ at $37^{\circ} \mathrm{C}$ was adjusted either upward ( $\mathrm{pH} 7.8$ ) by addition of $\mathrm{NaOH}$ or downward ( $\mathrm{pH} 7 \cdot 2$ or $7 \cdot 0$ ) by addition of $\mathrm{HCl}$. The osmolality of each of the resulting experimental buffers was 2-3 mosmol greater than the osmolality of the control buffer. No corrections for differences in osmolalities between control and experimental buffers were made. Final adjustments of $\mathrm{pH}$ of all buffers were made immediately prior to use. Specific additions to these buffers are noted for individual experiments.

\section{Design and statistics}

Temporal effects of $\mathrm{pH}_{\mathrm{o}}$ or AngII on $\left[\mathrm{Ca}^{2+}\right]_{\mathrm{i}}$ were evaluated by comparing the average $\left[\mathrm{Ca}^{2+}\right]_{i}$ measured during the peak (4-5 min) or plateau (14-15 and 44-45 min) phase of the response and the average $\left[\mathrm{Ca}^{2+}\right]_{\mathrm{i}}$ measured during the minute immediately preceding the change in $\mathrm{pH}_{\mathrm{o}}$ or the addition of agonist. Average $\left[\mathrm{Ca}^{2+}\right]_{\mathrm{i}}$ over equivalent periods was determined for control cells. In instances when the calcium signal was integrated to obtain an area-under-the-curve (AUC), the signal was first corrected for any slope in baseline $\left[\mathrm{Ca}^{2+}\right]_{\mathrm{i}}$. The effects of each experimental regimen were examined, for the most part, using individual monolayers from a single cell preparation. In cases where the effect of a given experimental regimen was examined using multiple monolayers from the same cell preparation, replicates were averaged to give a single value. Similarly, aldosterone secretion was assayed in triplicate using individual monolayers derived from a single cell preparation, replicates for each experimental condition representing monolayers from separate multiwell clusters. Results for each condition were averaged to give a single value, and the experiment repeated using independent cell preparations. Within an individual experiment (and, to the extent possible, between experiments), the times between the onset of superfusion (or incubation) with buffer of $\mathrm{pH} 7 \cdot 4$ and exposure of cells to buffer of another $\mathrm{pH}$ or agonist were constant between groups. All results are expressed as the mean \pm S.E.M with $n$ representing the number of distinct cell preparations. Unless otherwise indicated, each experiment was repeated a minimum of four times. ANOVA followed by the Newman-Keul test for comparison of means was used to determine the effects of experimental treatments. A value of $P \leq 0.05$ was accepted as significant.

\section{Results}

Effects of changes in $\mathrm{pH}_{\mathrm{o}}$ on $\left[\mathrm{Ca}^{2+}\right]_{i}$

Reductions in $\mathrm{pH}_{\mathrm{o}}$ from $7 \cdot 4\left(40 \mathrm{nM} \mathrm{H}^{+}\right)$to $7 \cdot 2$ or $7 \cdot 0(63$ or $100 \mathrm{nM} \mathrm{H}^{+}$) caused graded increases in $\left[\mathrm{Ca}^{2+}\right]_{\mathrm{i}}$ that were characterized by an initial peak and a secondary plateau (Fig. 1A, Table 1). In response to a decrease in $\mathrm{pH}_{\mathrm{o}}$ from $7 \cdot 4$ to $7 \cdot 0$, for example, $\left[\mathrm{Ca}^{2+}\right]_{\mathrm{i}}$ increased over 2-fold ( $254 \pm 23$ versus $113 \pm 7 \mathrm{nM}$ ) within 4-5 min and then declined rapidly over the next 5-10 min and more slowly thereafter. Thirty minutes after the reduction in $\mathrm{pH}_{\mathrm{o}},\left[\mathrm{Ca}^{2+}\right]_{\mathrm{i}}$ remained at a level greater than that of control cells (135 \pm 7 vs $114 \pm 8 \mathrm{nM}$ ). A smaller reduction in $\mathrm{pH}_{\mathrm{o}}$ (i.e. from $\mathrm{pH} 7 \cdot 4$ to $7 \cdot 2$ ) caused proportionately smaller increases in $\left[\mathrm{Ca}^{2+}\right]_{i}$ during both the peak and plateau phases of the $\mathrm{Ca}^{2+}$ signal. In contrast to the effects of a reduction in $\mathrm{pH}_{\mathrm{o}}$, an elevation in $\mathrm{pH}_{\mathrm{o}}$ from $7 \cdot 4$ to $7 \cdot 8$ (corresponding to a decrease in $\left[\mathrm{H}^{+}\right]_{\mathrm{o}}$ from 40 to $16 \mathrm{nM}$ ) had no effect on $\left[\mathrm{Ca}^{2+}\right]_{\mathrm{i}}($ Table 1$)$.

A comparison of the $\mathrm{Ca}^{2+}$ signal elicited by $\mathrm{H}^{+}$with those elicited by $\mathrm{K}^{+}$and AngII is presented in Fig. 1B. Although the $\mathrm{Ca}^{2+}$ signal elicited by reduction of $\mathrm{pH}_{\mathrm{o}}$ from $7 \cdot 4$ to $7 \cdot 0$, like the signal elicited by AngII 

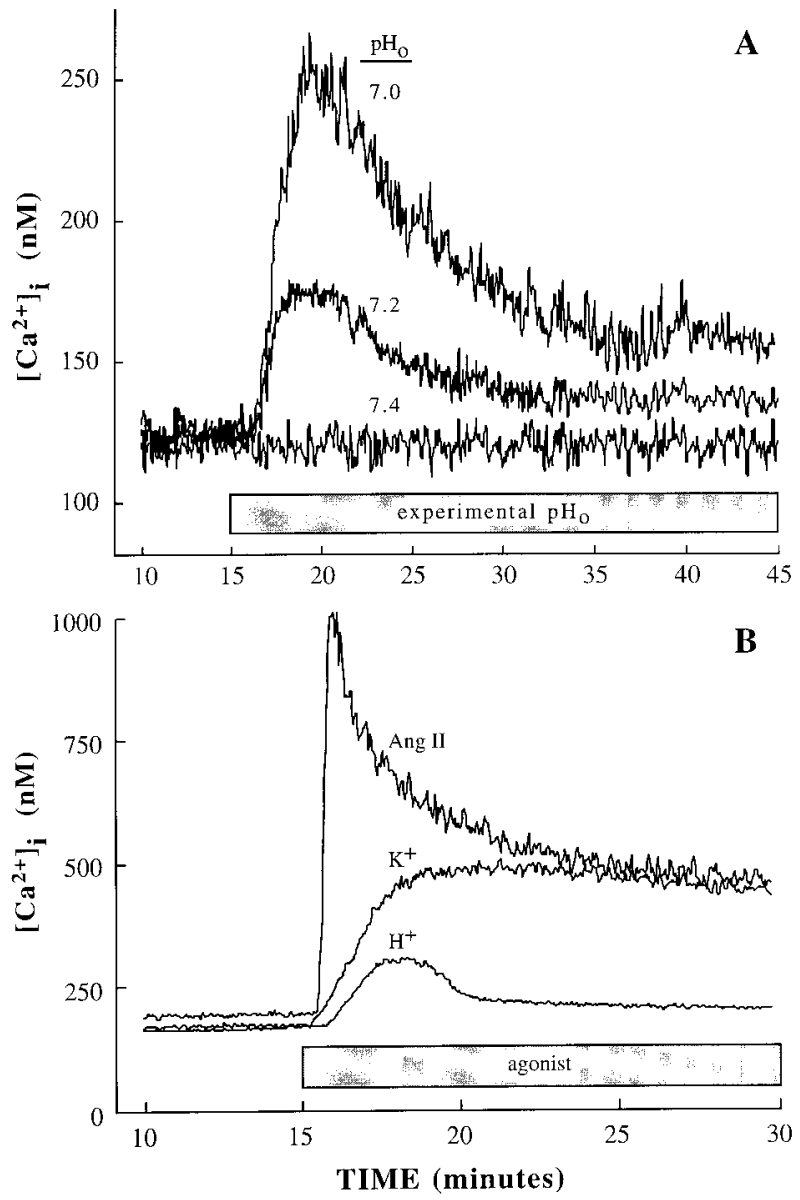

Figure 1 Cytosolic $\mathrm{Ca}^{2+}$ signal caused by reduction of $\mathrm{pH}_{\mathrm{o}}$. (A) $\left[\mathrm{Ca}^{2+}\right]_{\mathrm{i}}$ was monitored during superfusion of fura2-loaded glomerulosa cells with HBSS/Hepes buffer. Individual monolayers first were superfused for 15 min with buffer of $\mathrm{pH} 7 \cdot 4$. Then, $\mathrm{pH}_{0}$ was held at $7 \cdot 4$ or decreased to $7 \cdot 2$ or $7 \cdot 0$, and superfusion continued for an additional $30 \mathrm{~min}$. Data presented are from a single experiment using individual coverslips for each $\mathrm{pH}_{\mathrm{o}}$. (B) Adherent fura2-loaded glomerulosa cells were superfused for 15 min with HBSS/Hepes buffer that was adjusted to $\mathrm{pH} 7 \cdot 4$ and contained $4 \mathrm{mM} \mathrm{K}^{+}$. Next, cells were exposed for an additional 15 min to superfusate that had been adjusted to $\mathrm{pH} 7 \cdot 0\left(\mathrm{H}^{+}\right)$or that contained $1 \times 10^{-9} \mathrm{nM}$ Ang II or $15 \mathrm{mM} \mathrm{K}^{+}$. Each line represents the average of two determinations using individual monolayers in a single experiment. The $\mathrm{Ca}^{2+}$ signal elicited by $\mathrm{H}^{+}$ is representative of those noted in response to a similar reduction in $\mathrm{pH}_{\mathrm{o}}$ during the course of the present studies, whereas the $\mathrm{Ca}^{2+}$ signals elicited by $\mathrm{K}^{+}$and Ang II are comparable to those noted in our previous studies using primary monolayer cultures of bovine glomerulosa cells.

$\left(\geq 1 \times 10^{-9} \mathrm{M}\right)$, exhibited an initial peak and secondary plateau, it was considerably smaller in magnitude than was the signal elicited by a maximal concentration of either AngII or $\mathrm{K}^{+}$.

The nature of the $\mathrm{Ca}^{2+}$ signal elicited by reductions in $\mathrm{pH}_{\mathrm{o}}$ was independent of whether Hepes or bicarbonate was the primary extracellular buffer. A reduction of $\mathrm{pH}_{\mathrm{o}}$ from $7 \cdot 4$ to $7 \cdot 0$ during superfusion of cells with bicarbonate-buffered medium elicited both a peak $(156 \pm 18 \mathrm{nM})$ and plateau $(22 \pm 7 \mathrm{nM})$ in $\left[\mathrm{Ca}^{2+}\right]_{\mathrm{i}}$ that were comparable to the increases $(155 \pm 13$ and $31 \pm 4 \mathrm{nM}$ respectively) elicited during superfusion of cells with Hepes-buffered medium $(n=4)$.

Effects of changes in $\mathrm{pH}_{0}$ on $\mathrm{Ca}^{2+}$ fluxes

Alterations in $\mathrm{pH}_{\mathrm{o}}$ caused changes in ${ }^{45} \mathrm{Ca}^{2+}$ efflux that generally paralleled their effects on $\left[\mathrm{Ca}^{2+}\right]_{\mathrm{i}}$ (Fig. 2A, Table 1). A decrease in $\mathrm{pH}$ of the superfusate from $7 \cdot 4$ to $7 \cdot 2$ increased $\mathrm{Ca}^{2+}$ efflux from a basal rate of $2 \cdot 4 \pm 0 \cdot 2 \%$ / min to a maximal rate of $3.9 \pm 0.6 \% / \mathrm{min}$, whereas a reduction in superfusate $\mathrm{pH}$ from $7 \cdot 4$ to $7 \cdot 0$ increased the rate of $\mathrm{Ca}^{2+}$ efflux to a maximum of $5 \cdot 6 \pm 0.8 \% / \mathrm{min}$. Rates of $\mathrm{Ca}^{2+}$ efflux subsequently declined during sustained reductions in $\mathrm{pH}_{\mathrm{o}}$. In cells superfused continuously with buffer of $\mathrm{pH} 7 \cdot 0$, the rate of $\mathrm{Ca}^{2+}$ efflux fell during a $20 \mathrm{~min}$ period to a level about $1 \cdot 4$-fold greater than the rate of $\mathrm{Ca}^{2+}$ efflux from control cells, whereas the rate of $\mathrm{Ca}^{2+}$ efflux from cells superfused continuously with medium of $\mathrm{pH} 7 \cdot 2$ returned to near control levels. The rate of $\mathrm{Ca}^{2+}$ efflux was not affected by an elevation in the $\mathrm{pH}$ of the superfusate from $7 \cdot 4$ to $7 \cdot 8$.

A reduction of $\mathrm{pH}_{\mathrm{o}}$ from $7 \cdot 4$ to $7 \cdot 0$ enhanced the initial rate of $\mathrm{Ca}^{2+}$ influx from $15 \cdot 5 \pm 3 \cdot 0$ to $143 \cdot 2 \pm 20 \cdot 3$ c.p.m./s per mg protein (Fig. 2B), whereas an elevation of $\mathrm{pH}_{\mathrm{o}}$ to $7 \cdot 8 \mathrm{had}$ no effect. Within $40-60 \mathrm{~s}$, however, the rate of $\mathrm{Ca}^{2+}$ accumulation in cells exposed to $\mathrm{pH}_{\mathrm{o}} 7 \cdot 0$ paralleled that of control cells.

\section{Effects of changes in $\mathrm{pH}_{\mathrm{o}}$ on aldosterone secretion}

The rate of aldosterone secretion by cells incubated in medium of $\mathrm{pH} 7 \cdot 4\left(40 \mathrm{nM} \mathrm{H}^{+}\right)$was $23 \cdot 3 \pm 1 \cdot 4 \mathrm{pmol} / 2 \mathrm{~h}$ per mg protein $(n=8)$. An elevation of $\mathrm{pH}_{\mathrm{o}}$ from $7 \cdot 4$ to $7 \cdot 8\left(16 \mathrm{nM} \mathrm{H}^{+}\right)$did not affect the rate of aldosterone secretion $(21.9 \pm 1 \cdot 1)$. In contrast, reductions in $\mathrm{pH}_{\mathrm{o}}$ caused increases in the rate of aldosterone secretion that correlated closely with $\mathrm{H}^{+}$-stimulated increases in $\left[\mathrm{Ca}^{2+}\right]_{\mathrm{i}}$ (Fig. 3). Aldosterone secretion increased approximately 1.5 -fold $(34.7 \pm 2.8)$ in response to a reduction of $\mathrm{pH}_{\mathrm{o}}$ from $7 \cdot 4$ to $7 \cdot 2\left(63 \mathrm{nM} \mathrm{H}^{+}\right)$and approximately 2-fold $(46 \cdot 82 \pm 3 \cdot 6)$ in response to a reduction of $\mathrm{pH}_{\mathrm{o}}$ to $7 \cdot 0$ $\left(100 \mathrm{nM} \mathrm{H}^{+}\right)$. These rates of aldosterone secretion elicited by reductions in $\mathrm{pH}_{\mathrm{o}}$ compare to maximal rates of aldosterone secretion elicited by AngII $\left(1 \times 10^{-8} \mathrm{M}\right)$ and $\mathrm{K}^{+}(15 \mathrm{mM})$ of $261 \cdot 6 \pm 8 \cdot 0$ and $194 \cdot 7 \pm 12 \cdot 7 \mathrm{pmol} / 2 \mathrm{~h}$ per mg protein respectively.

\section{Role of extracellular $\mathrm{Ca}^{2+}$ in the actions of $\mathrm{H}^{+}$}

In the presence of extracellular $\mathrm{Ca}^{2+}$, there is a close correlation between $\mathrm{H}^{+}$-induced increases in $\left[\mathrm{Ca}^{2+}\right]_{\mathrm{i}}$ and aldosterone secretion (Fig. 3). In the absence of 
Table 1 Summary of time-dependent changes in $\left[\mathrm{Ca}^{2+}\right]_{\mathrm{i}}$ and transmembrane $\mathrm{Ca}^{2+}$ fluxes caused by alterations in $\mathrm{pH}_{\mathrm{o}}$. For the measurement of $\left[\mathrm{Ca}^{2+}\right]_{\mathrm{i}}$ and $\mathrm{Ca}^{2+}$ efflux, cells previously loaded with fura 2 and ${ }^{45} \mathrm{Ca}^{2+}$ were superfused for an initial 15 min control period with buffer of $\mathrm{pH} 7 \cdot 4$ and then for a 25-30 min experimental period during which the $\mathrm{pH}$ of the superfusate was $7 \cdot 0,7 \cdot 2,7 \cdot 4$ or $7 \cdot 8$. Data for each experimental group represent the differences between values measured at the end of the control period and those measured at the indicated times after the start of the experimental period. Changes in $\left[\mathrm{Ca}^{2+}\right]_{\mathrm{i}}$ and $\mathrm{Ca}^{2+}$ efflux during the experimental period are indicated also by $\mathrm{AUC}\left(\mathrm{nM} \bullet \mathrm{min}\right.$ or percent $\bullet \mathrm{min}$, as appropriate). Values for $\left[\mathrm{Ca}^{2+}\right]_{\mathrm{i}}$ represent the mean \pm S.E.M. of six to eight independent determinations, whereas values for ${ }^{45} \mathrm{Ca}^{2+}$ efflux represent the mean \pm S.E.M. of four determinations. Initial rates of $\mathrm{Ca}^{2+}$ influx were calculated from the accumulation of ${ }^{45} \mathrm{Ca}^{2+}$ in cells incubated in buffer of the indicated $\mathrm{pH}_{\mathrm{o}}$ and are expressed as the mean \pm S.E.M. of five experiments

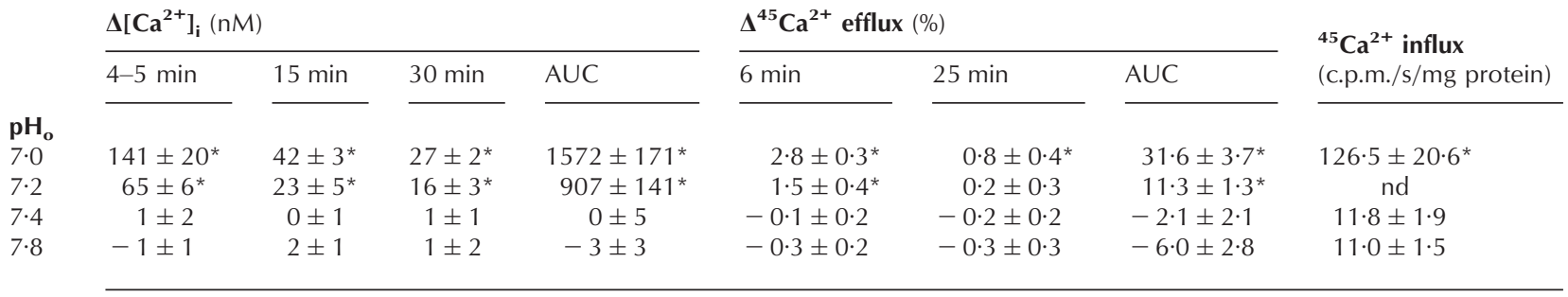

nd, not determined; ${ }^{*} P<0 \cdot 05 \mathrm{vs}^{\mathrm{pH}_{\mathrm{o}}} 7 \cdot 4$.

extracellular $\mathrm{Ca}^{2+}$ (i.e. $\mathrm{Ca}^{2+}$-free buffer containing $0.05 \mathrm{mM}$ EGTA), increases in $\left[\mathrm{Ca}^{2+}\right]_{\mathrm{i}}$ and $\mathrm{Ca}^{2+}$ efflux caused by reduction of $\mathrm{pH}_{\mathrm{o}}$ from $7 \cdot 4$ to $7 \cdot 0$ were abolished (Table 2). Removal of extracellular $\mathrm{Ca}^{2+}$ also abolished the increase in aldosterone secretion caused by acidification $\left(\mathrm{pH}_{\mathrm{o}} 7 \cdot 0\right)$ of the extracellular medium (Table 2). In contrast, rates of aldosterone secretion by cells incubated under control $\left(\mathrm{pH}_{\mathrm{o}} 7 \cdot 4 ; 26 \cdot 6 \pm 1 \cdot 2 \mathrm{vs} 27 \cdot 1 \pm 1 \cdot 5 \mathrm{pmol} /\right.$ $2 \mathrm{~h}$ per mg protein) or alkalotic $\left(\mathrm{pH}_{\mathrm{o}} 7 \cdot 8 ; 25 \cdot 4 \pm 1 \cdot 6 \mathrm{vs}\right.$ $23.4 \pm 1.2 \mathrm{pmol} / 2 \mathrm{~h}$ per $\mathrm{mg}$ protein) conditions in the absence of extracellular $\mathrm{Ca}^{2+}$ were similar to rates of secretion in the presence of extracellular $\mathrm{Ca}^{2+}$.

\section{Effects of $\mathrm{pH}_{o}$ on AngII-stimulated increases in $\left[\mathrm{Ca}^{2+}\right]_{i}$ and} aldosterone secretion

The ability of AngII to increase $\left[\mathrm{Ca}^{2+}\right]_{\mathrm{i}}$ was compared in control $\left(\mathrm{pH}_{\mathrm{o}} 7 \cdot 4\right)$ cells and cells exposed to acidotic $\left(\mathrm{pH}_{\mathrm{o}}\right.$ 7.0) conditions for $15 \mathrm{~min}$. At the time of addition of AngII, initial transients in $\left[\mathrm{Ca}^{2+}\right]_{\mathrm{i}}$ caused by reduction of $\mathrm{pH}_{\mathrm{o}}$ had subsided, and $\left[\mathrm{Ca}^{2+}\right]_{\mathrm{i}}$ had achieved a new steady-state (Fig. 4). The results of a representative experiment in which $\mathrm{pH}_{\mathrm{o}}$ was decreased from $7 \cdot 4$ to $7 \cdot 0$ prior to stimulation with AngII are presented in Fig. 4A and B, and a summary of the results of four to six independent experiments is presented in Fig. 4C.

Prior acidification of the extracellular medium (i.e. reduction of $\mathrm{pH}_{\mathrm{o}}$ from $7 \cdot 4$ to $7 \cdot 0$ ), attenuated the increase in $\left[\mathrm{Ca}^{2+}\right]_{\mathrm{i}}$ caused by $1 \times 10^{-10} \mathrm{M}$ AngII, as evidenced by decreases in the rate-of-rise, the final magnitude and AUC of the $\mathrm{Ca}^{2+}$ signal. In contrast, the $\mathrm{Ca}^{2+}$ signal caused by $1 \times 10^{-8} \mathrm{M}$ AngII was not affected. At the lower concentration of AngII, the combined integrated $\mathrm{Ca}^{2+}$ signal (i.e. AUC) for $\mathrm{H}^{+}\left(\mathrm{pH}_{\mathrm{o}} 7 \cdot 0\right)$ plus AngII approximated the integrated signal for AngII alone at $\mathrm{pH} 7 \cdot 4$ (Fig. 4C). At $1 \times 10^{-8} \mathrm{M}$ AngII, in contrast, the combined integrated
$\mathrm{Ca}^{2+}$ signal for $\mathrm{H}^{+}$plus AngII was greater than that for AngII alone.

AngII-stimulated aldosterone secretion was not affected by an increase of $\mathrm{pH}_{\mathrm{o}}$ from $7 \cdot 4$ to $7 \cdot 8$, but it was augmented by a reduction of $\mathrm{pH}_{\mathrm{o}}$ to $7 \cdot 0$ (Fig. 5). The enhanced aldosterone secretion caused by extracellular acidification was manifested as an increase in the magnitude of the response rather than by an increase in the sensitivity to AngII; the $\mathrm{EC}_{50}$ of AngII at both $\mathrm{pH}_{\mathrm{o}} 7 \cdot 4$ and $7 \cdot 0$ was approximately $7 \times 10^{-10} \mathrm{M}$. Nonetheless, when the increase in aldosterone secretion caused by AngII $\left(1 \times 10^{-11}, 1 \times 10^{-10}\right.$ and $\left.1 \times 10^{-8} \mathrm{M}\right)$ is examined as a function of the integrated AngII-stimulated $\mathrm{Ca}^{2+}$ signal (Fig. 6), it is apparent that a reduction of $\mathrm{pH}_{\mathrm{o}}$ from $7 \cdot 4$ to $7 \cdot 0$ increased the sensitivity and gain of a more distal component(s) of the signaling cascade or the steroidogenic pathway to $\mathrm{Ca}^{2+}$. For comparison, the increase in aldosterone secretion caused by both $\mathrm{H}^{+}$and AngII is also presented as a function of the sum of their integrated $\mathrm{Ca}^{2+}$ signals. As expected, the total steroidogenic response under acidotic conditions, as is the response under control conditions $\left(\mathrm{pH}_{\mathrm{o}} 7 \cdot 4\right)$, is directly related to the magnitude of the $\mathrm{Ca}^{2+}$ signal.

\section{Discussion}

The premise that $\mathrm{H}^{+}$(i.e. $\mathrm{pH}_{\mathrm{o}}$ ) has a modulatory role in the control of aldosterone secretion arose from correlations between plasma aldosterone concentration and acid-base status (Christleib et al. 1975, Kassirer et al. 1976, Perez et al. 1977, 1979, 1980, Schambelan \& Sebastian 1977, Scott et al. 1978, Raff \& Roarty 1988, Julian et al. 1982). The premise developed further in light of the ability of alterations in $\mathrm{pH}_{\mathrm{o}}$ to affect aldosterone secretion in vitro (Muller 1965, Chiu \& Freer 1979, Gilchrist et al. 1983, 

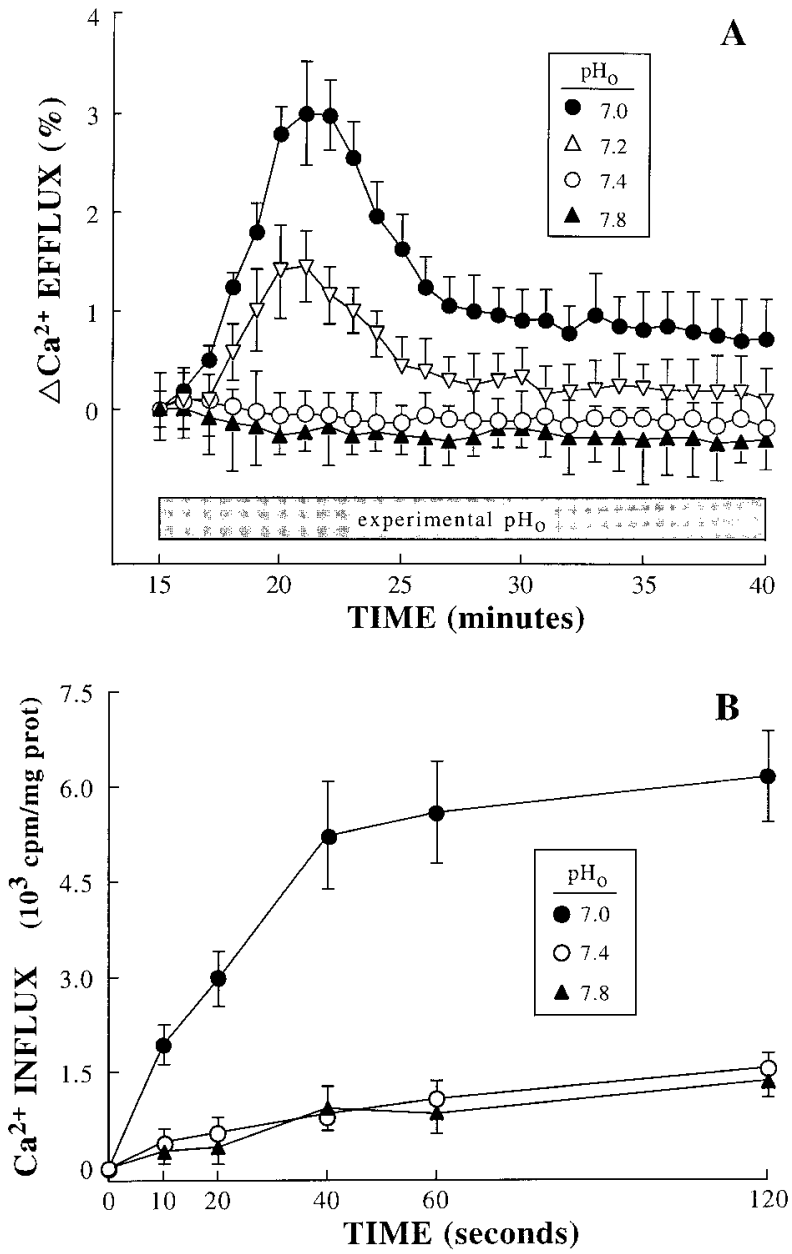

Figure 2 Effects of changes in $\mathrm{pH}_{\mathrm{o}}$ on transmembrane $\mathrm{Ca}^{2+}$ fluxes. Calcium efflux (A) was monitored simultaneously with $\left[\mathrm{Ca}^{2+}\right]_{i}$ (see Fig. 1A) during superfusion of adherent glomerulosa cells previously loaded with fura 2 and ${ }^{45} \mathrm{Ca}^{2+}$. Individual monolayers first were superfused with buffer of $\mathrm{pH} 7 \cdot 4$ for $15 \mathrm{~min}$ and then for an additional 30 min with buffer of the indicated $\mathrm{pH}$. Data are presented as the mean \pm S.E.M. of four experiments. For the measurement of $\mathrm{Ca}^{2+}$ influx (B), cells were incubated initially in HBSS/Hepes buffer of $\mathrm{pH} 7 \cdot 4$ for $60 \mathrm{~min}$ and then in fresh buffer of $\mathrm{pH} 7 \cdot 4, \mathrm{pH} 7 \cdot 0$ or $\mathrm{pH} 7 \cdot 8$ containing $2 \mu \mathrm{Ci}^{45} \mathrm{Ca}^{2+}$ Intracellular accumulation of ${ }^{45} \mathrm{Ca}^{2+}$ was terminated at the indicated times by the addition of an equal volume of cold $\mathrm{LaCl}_{3} / \mathrm{Mg}\left(\mathrm{C}_{2} \mathrm{H}_{3} \mathrm{O}_{2}\right)_{2} \bullet 4 \mathrm{H}_{2} \mathrm{O}(20 \mathrm{mM} / 200 \mathrm{mM}$, pH 6.0) solution. Values are expressed as the mean \pm S.E.M. of five experiments.

Carroll et al. 1986, Radke et al. 1986a,b). Results of the present studies extend these previous observations and demonstrate that $\mathrm{H}^{+}$acts directly on glomerulosa cells to increase aldosterone secretion. Importantly, the effect of $\mathrm{H}^{+}$to increase aldosterone secretion was apparent over a range of $\mathrm{pH}_{\mathrm{o}}$ in vitro that is compatible with the range of plasma $\mathrm{pH}$ evidenced in vivo under physiological and pathophysiological conditions (Singer \& Hastings 1948).
Reductions of $\mathrm{pH}_{\mathrm{o}}$ from $7 \cdot 4$ to $7 \cdot 2$ or $7 \cdot 0$ resulted in proportionate increases in the basal rate of aldosterone secretion. Given the action of aldosterone to promote $\mathrm{Na}^{+}$ reabsorption by the collecting tubule and the reciprocal relationship between $\mathrm{Na}^{+}$reabsorption and $\mathrm{H}^{+}$excretion, an increase in aldosterone secretion resulting from a direct action of $\mathrm{H}^{+}$on glomerulosa cells might elicit a compensatory increase in proton excretion that contributes to the restoration of acid-base status during periods of acidosis. If such a mechanism operates in vivo, the present data suggest that it operates predominantly, if not solely, in response to an acid load. This seems incongruous with the conservation of $\mathrm{H}^{+}$that might be achieved secondary to a decrease in $\mathrm{Na}^{+}$reabsorption during alkalosis. However, independent effects of $\mathrm{H}^{+}$on aldosterone secretion may be less important under such circumstances than are effects resulting from its interaction with other agonists. In this context, metabolic alkalosis induced by infusion of $\mathrm{NaHCO}_{3}$ in humans was associated with a fall in serum aldosterone without an accompanying change in serum $\mathrm{K}^{+}$, ACTH or renin activity (Jones et al. 1992, Yamauchi et al. 1997). Also, AngII- and $\mathrm{K}^{+}$-stimulated aldosterone secretion by perfused canine adrenal glands were attenuated by increases in $\mathrm{pH}_{\mathrm{o}}$ comparable to those of the present study (Radke et al. 1986a,b).

A modulatory role for $\mathrm{pH}_{\mathrm{o}}$ in the regulation of aldosterone secretion is reinforced by comparison of the cytosolic $\mathrm{Ca}^{2+}$ and steroidogenic responses elicited by $\mathrm{H}^{+}$ with those elicited by AngII or $\mathrm{K}^{+}$. Whereas AngII $\left(1 \times 10^{-8} \mathrm{M}\right)$ and $\mathrm{K}^{+}(15 \mathrm{mM})$ caused approximately 10 -fold increases in aldosterone secretion, $\mathrm{H}^{+}(100 \mathrm{nM}$; $\mathrm{pH} 7 \cdot 0$ ) increased aldosterone secretion only about 2 -fold over the same period. Also, the final increase in $\left[\mathrm{Ca}^{2+}\right]_{\mathrm{i}}$ caused by $100 \mathrm{nM} \mathrm{H}^{+}$was about one-tenth the increase caused by AngII or $\mathrm{K}^{+}$. Finally, the ability of $\mathrm{H}^{+}$to modulate increases in $\left[\mathrm{Ca}^{2+}\right]_{\mathrm{i}}$ in and aldosterone secretion by cultured glomerulosa cells caused by a low concentration (e.g. $1 \times 10^{-11} \mathrm{M}$ ) of AngII is not apparent at a maximal concentration $\left(1 \times 10^{-8} \mathrm{M}\right)$ of AngII.

Comparisons of the data obtained in the present studies with data obtained over a similar range of $\mathrm{pH}_{\mathrm{o}}$ in previous studies suggests an increased complexity to the actions of $\mathrm{H}^{+}$as well as the regulation of aldosterone secretion. For instance, Raff \& Jankowski (1993) using bovine glomerulosa cells within $24-48 \mathrm{~h}$ of isolation failed to observe a change in basal aldosterone secretion in response to a reduction of $\mathrm{pH}_{\mathrm{o}}$ from about $7 \cdot 2$ to $7 \cdot 0-6 \cdot 8$. Gilchrist et al. (1983) using freshly isolated rat glomerulosa cells reported that basal aldosterone secretion was inhibited by both a reduction in $\mathrm{pH}_{\mathrm{o}}$ from $7 \cdot 4$ to $7 \cdot 1-6.8$ and an elevation of $\mathrm{pH}_{\mathrm{o}}$ to $7 \cdot 7$. Furthermore, Radke et al. $(1986 a, b)$ reported that basal aldosterone secretion by isolated perfused canine adrenal glands did not change in response to a decrease in $\mathrm{pH}_{\mathrm{o}}$ from $7 \cdot 4$ to approximately $7 \cdot 2$, but increased in response to an elevation of $\mathrm{pH}_{0}$ to approximately $7 \cdot 8$. 


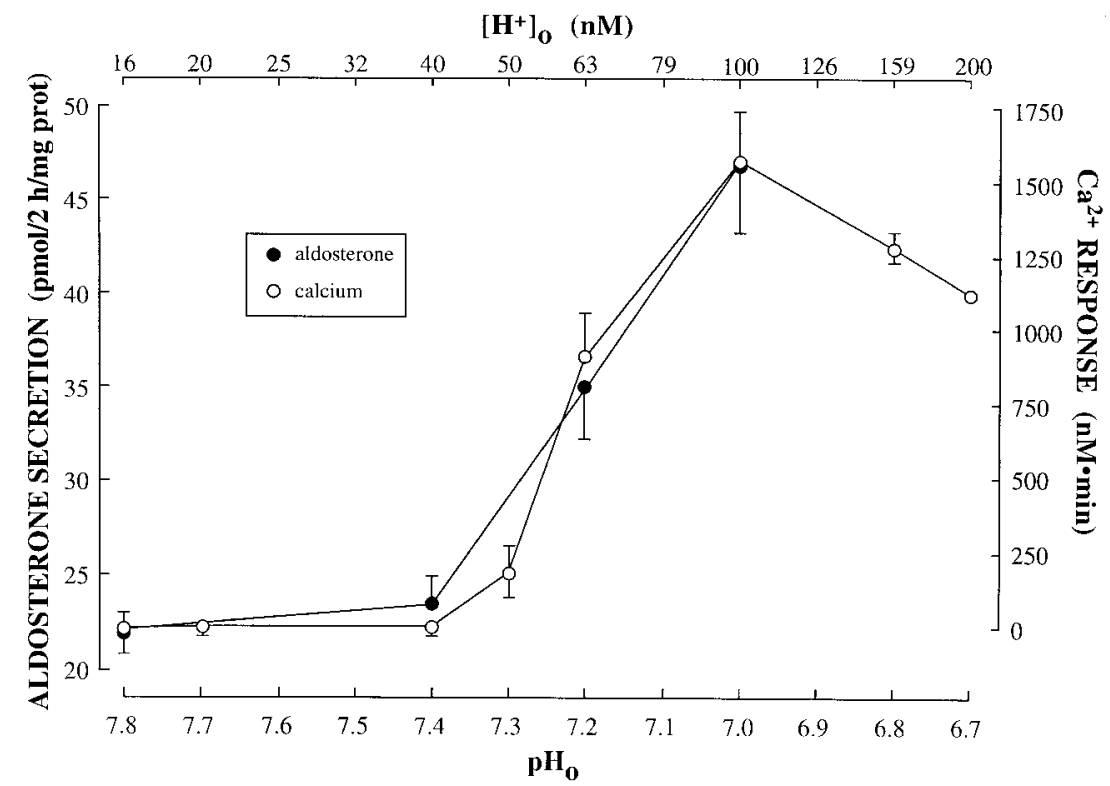

Figure 3 Relationships between $\mathrm{pH}_{\mathrm{o}}$, aldosterone secretion and $\left[\mathrm{Ca}^{2+}\right]_{\mathrm{i}}$. Aldosterone secretion was allowed to proceed for $2 \mathrm{~h}$ during static incubations of glomerulosa cells in HBSS/Hepes buffer adjusted to $\mathrm{pH} 7 \cdot 0,7 \cdot 2,7 \cdot 4$ or $7 \cdot 8$. Values represent the mean \pm S.E.M. obtained from six to eight experiments. In each experiment, triplicate monolayers were incubated under each condition, and replicates averaged. Changes in $\left[\mathrm{Ca}^{2+}\right]_{i}$ caused by alterations in $\mathrm{pH}_{\mathrm{o}}$ from $7 \cdot 4$ were determined in four of the same cell preparations in which aldosterone secretion was measured. The $\mathrm{Ca}^{2+}$ response was integrated over the initial 15 min of the experimental period (see Fig. 1 for details) and is presented as an AUC.

Values are presented as mean \pm S.E.M.

Some discrepancies between results of these and the present studies may be attributed to alterations in extracellular $\mathrm{Na}^{+}$concentration $\left[\mathrm{Na}^{+}\right]_{\mathrm{o}}$, osmolality or initial $\mathrm{pH}_{\mathrm{o}}$; reasons for others are not readily explained. Although buffers as well as the means used to alter $\mathrm{pH}_{\text {o }}$ differed between studies, Radke et al. $(1986 a, b)$ concluded that the effects observed using perfused adrenal glands resulted from $\mathrm{H}^{+}$per se. Similarly, in cultured bovine glomerulosa cells, $\mathrm{H}^{+}$- and AngII-induced changes in $\mathrm{pH}_{\mathrm{i}}$, $\left[\mathrm{Ca}^{2+}\right]_{\mathrm{i}}$ and aldosterone secretion are qualitatively similar in Hepes- and bicarbonate-buffered media (Kramer 1991, R E Kramer, unpublished observations). Possibly, some

Table 2 Relationship of extracellular $\mathrm{Ca}^{2+}$ to $\mathrm{H}^{+}$-stimulated $\mathrm{Ca}^{2+}$ signals and aldosterone secretion. The effects of a reduction in $\mathrm{pH} \mathrm{O}_{\mathrm{o}}$ from $7 \cdot 4$ to $7 \cdot 0$ on $\left[\mathrm{Ca}^{2+}\right]_{\mathrm{i}}, \mathrm{Ca}^{2+}$ efflux and aldosterone secretion were compared in the presence $\left(+\mathrm{Ca}^{2+}, 1 \cdot 8 \mathrm{mM} \mathrm{CaCl}_{2}\right)$ and absence $\left(-\mathrm{Ca}^{2+}\right.$; nominal $\mathrm{Ca}^{2+}+0.05 \mathrm{mM}$ EGTA) of extracellular $\mathrm{Ca}^{2+}$. Measurements of $\left[\mathrm{Ca}^{2+}\right]_{\mathrm{i}}$ and $\mathrm{Ca}^{2+}$ efflux were made simultaneously. After being loaded with both fura2 and ${ }^{45} \mathrm{Ca}^{2+}$, one set of cells $\left(+\mathrm{Ca}^{2+}\right)$ was superfused with $\mathrm{HBSS} /$ Hepes buffer $(\mathrm{pH} 7 \cdot 4) \mathrm{containing} 1 \cdot 8 \mathrm{mM} \mathrm{CaCl}{ }_{2}$ for $20 \mathrm{~min}$ and then with buffer of $\mathrm{pH} 7 \cdot 0$ for $15 \mathrm{~min}$. A second set $\left(-\mathrm{Ca}^{2+}\right)$ was superfused sequentially with $\mathrm{HBSS} / \mathrm{Hepes}$ buffer $(\mathrm{pH}$ $7 \cdot 4,1.8 \mathrm{mM} \mathrm{CaCl}_{2}$ ) for $15 \mathrm{~min}$, nominal $\mathrm{Ca}^{2+} / \mathrm{EGTA}$ buffer of $\mathrm{pH} 7 \cdot 4$ for $5 \mathrm{~min}$ and, finally, nominal $\mathrm{Ca}^{2+} / \mathrm{EGTA}$ buffer of $\mathrm{pH} 7 \cdot 0$ for 15 min. Peak $(4-5 \mathrm{~min})$ and plateau $(15 \mathrm{~min})$ values for $\left[\mathrm{Ca}^{2+}\right]_{\mathrm{i}}$ and ${ }^{45} \mathrm{Ca}^{2+}$ efflux are in $\mathrm{nM}$ and percent respectively. In addition, changes in cytosolic $\left[\mathrm{Ca}^{2+}\right]_{i}$ and $\mathrm{Ca}^{2+}$ efflux during the final 15 min experimental period were integrated and are presented as AUC (nM•min and percent•min respectively). Aldosterone secretion was assayed during static incubations using cell preparations different from those used to measure changes in cell $\mathrm{Ca}^{2+}$. Rates of aldosterone secretion by control cells (Hepes buffer, $\mathrm{pH}_{\mathrm{o}} 7 \cdot 4$ ) were $26 \cdot 4 \pm 1 \cdot 5$ and $29 \cdot 6 \pm 2 \cdot 2 \mathrm{pmol} / 2 \mathrm{~h}$ per mg protein) respectively, in the presence and absence of extracellular $\mathrm{Ca}^{2+}$. All values represent the change elicited by reduction of $\mathrm{pH}_{\mathrm{o}}$ relative to control $\left(\mathrm{pH}_{\mathrm{o}} 7 \cdot 4\right)$ and are expressed as the mean \pm S.E.M. derived from four experiments

\begin{tabular}{|c|c|c|c|c|c|c|c|}
\hline & \multicolumn{3}{|c|}{$\Delta\left[\mathrm{Ca}^{2+}\right]_{\mathbf{i}}(\mathrm{nM}$ or $\mathrm{nM} \bullet \min )$} & \multicolumn{3}{|c|}{$\Delta^{45} \mathbf{C a}^{2+}$ efflux (\% or \%•min) } & \multirow{2}{*}{$\begin{array}{l}\Delta \text { Aldosterone } \\
\text { (pmol/2 h/mg protein) }\end{array}$} \\
\hline & $4-5 \min$ & $15 \mathrm{~min}$ & AUC & $4-5 \min$ & $15 \mathrm{~min}$ & AUC & \\
\hline Group & & & & & & & \\
\hline $\begin{array}{l}+\mathrm{Ca}^{2+} \\
-\mathrm{Ca}^{2+}\end{array}$ & $\begin{array}{l}139 \pm 20 \\
-1 \pm 1\end{array}$ & $\begin{aligned} 58 & \pm 9 \\
1 & \pm 1^{*}\end{aligned}$ & $\begin{array}{r}1213 \pm 74 \\
-1 \pm 4^{*}\end{array}$ & $\begin{aligned} 3 \cdot 1 & \pm 0 \cdot 3 \\
-0 \cdot 2 & \pm 0 \cdot 2^{*}\end{aligned}$ & $\begin{aligned} 1 \cdot 1 & \pm 0 \cdot 3 \\
-0 \cdot 3 & \pm 0 \cdot 2^{*}\end{aligned}$ & $\begin{aligned} 16 \cdot 4 & \pm 2 \cdot 0 \\
-4 \cdot 2 & \pm 3 \cdot 1^{*}\end{aligned}$ & $\begin{aligned} 20 \cdot 2 & \pm 2 \cdot 1 \\
-1 \cdot 6 & \pm 1 \cdot 4^{*}\end{aligned}$ \\
\hline
\end{tabular}

${ }^{*} \mathrm{P}<0 \cdot 05 \mathrm{vs}+\mathrm{Ca}^{2+}$. 

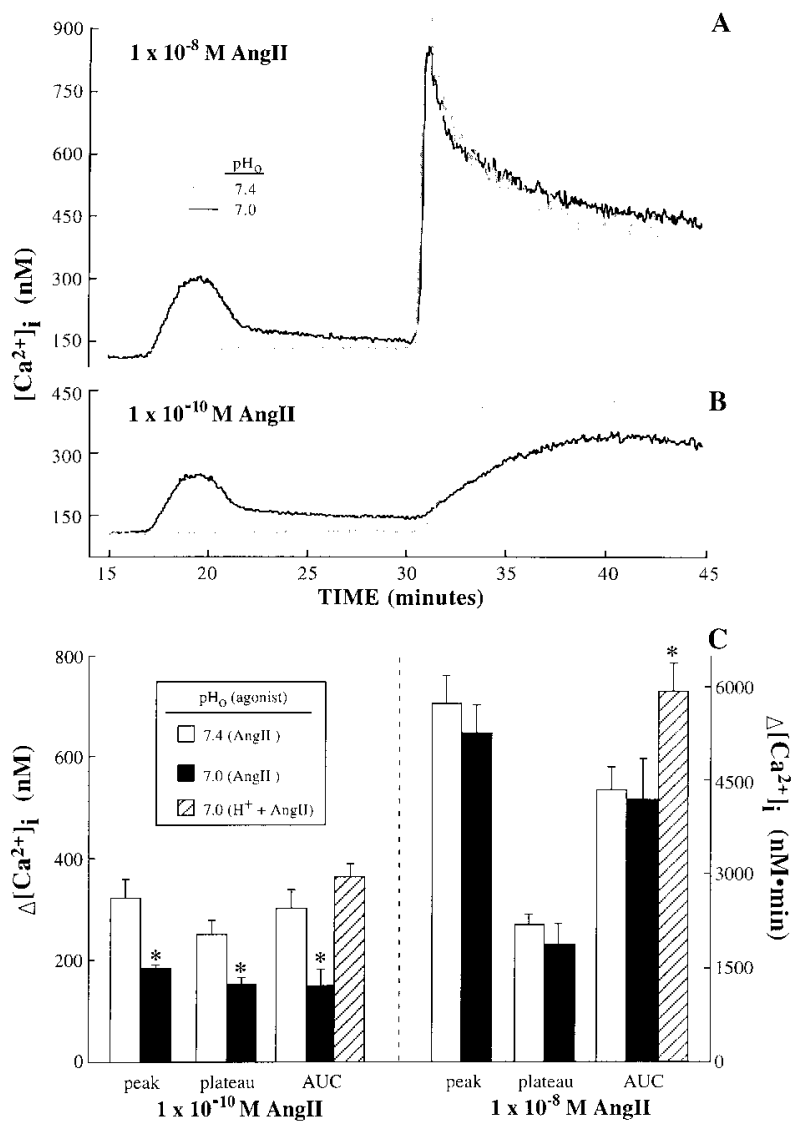

Figure 4 Changes in Angll-stimulated $\mathrm{Ca}^{2+}$ signals caused by reduction of $\mathrm{pH}_{\mathrm{o}}$. After being superfused with HBSS/Hepes buffer of $\mathrm{pH}_{\mathrm{o}} 7 \cdot 4$ for $15 \mathrm{~min}$, adherent fura2-loaded glomerulosa cells were superfused for an additional 30 min with buffer of $\mathrm{pH}_{\mathrm{o}} 7 \cdot 4$ or $7 \cdot 0$. Angll was added to the superfusate at $30 \mathrm{~min}$. Representative changes in $\left[\mathrm{Ca}^{2+}\right]_{\mathrm{i}}$ caused by reduction of $\mathrm{pH}_{\mathrm{o}}$ and by Angll $\left(1 \times 10^{-8} \mathrm{M}\right.$ or $\left.1 \times 10^{-10} \mathrm{M}\right)$ at $\mathrm{pH}_{\mathrm{o}} 7 \cdot 4$ and $7 \cdot 0$ are reported in $(\mathrm{A})$ and $(\mathrm{B})$, whereas mean \pm S.E.M. peak, plateau and $\mathrm{AUC}$ for Angll-stimulated $\mathrm{Ca}^{2+}$ signals from five to eight experiments are reported in (C). Peak values were measured 2-3 $\left(1 \times 10^{-8} \mathrm{M}\right)$ or $4-5\left(1 \times 10^{-10} \mathrm{M}\right)$ min after addition of Angll, whereas plateau values were determined after $15 \mathrm{~min}$. AUC for Angll-stimulated $\mathrm{Ca}^{2+}$ signals was calculated by integrating $\left[\mathrm{Ca}^{2+}\right]_{\mathrm{i}}$ from the time of addition of Angll to the end of the experimental period (i.e. from 30 to $45 \mathrm{~min}$ ). The combined integrated $\mathrm{Ca}^{2+}$ signal caused by $\mathrm{H}^{+}$and Angll was calculated from the time of reduction of $\mathrm{pH}_{\mathrm{o}}$ (i.e. $15 \mathrm{~min}$ ). ${ }^{*} P<0 \cdot 05$ versus the Angll response at $\mathrm{pH}_{\mathrm{o}} 7 \cdot 4$.

differences in aldosterone secretion observed following alterations in $\mathrm{pH}_{\mathrm{o}}$ result from the presence of factors in the intact adrenal gland or the whole animal that modulate the response to $\mathrm{H}^{+}$. These factors, or their effects on glomerulosa cells, may be lost during the course of primary culture. Likewise, a higher 'basal' activity of freshly isolated cells may make subtle changes in aldosterone secretion caused by alterations in $\mathrm{pH}_{\mathrm{o}}$ more readily apparent than they would be in cells maintained in long-term culture. Subtle differences in aldosterone secretion also may be more apparent during perfusion than during static incubations. And, possibly the response of glomerulosa cells to changes in $\mathrm{pH}_{\mathrm{o}}$ differs between species. Nonetheless, changes in aldosterone secretion by cultured bovine glomerulosa cells in response to reductions in $\mathrm{pH}_{\mathrm{o}}$ noted here are in accord with those noted in humans in response to reductions in plasma $\mathrm{pH}$ in the absence of apparent changes in other potentially confounding variables (Jones et al. 1992). Moreover, cultured bovine glomerulosa cells respond to other physiological variables in a manner expected of the adrenal gland in vivo (Schneider \& Kramer 1986, Kramer 1988a, Wang et al. 1992). In any event, the present data as well as much of the data from previous studies indicate that $\mathrm{H}^{+}$has a direct action on glomerulosa cells to increase aldosterone secretion.

The present data indicate that the mechanism by which $\mathrm{H}^{+}$increases aldosterone secretion is $\mathrm{Ca}^{2+}$-dependent. Increases in aldosterone secretion associated with reductions in $\mathrm{pH}_{\mathrm{o}}$ were accompanied by proportionate increases in $\left[\mathrm{Ca}^{2+}\right]_{\mathrm{i}}$ and $\mathrm{Ca}^{2+}$ efflux. The rate of $\mathrm{Ca}^{2+}$ influx was also increased upon initial reduction of $\mathrm{pH}_{\mathrm{o}}$, though this effect was not sustained. Nonetheless, influx of extracellular $\mathrm{Ca}^{2+}$ appears to be critical to the action of $\mathrm{H}^{+}$. Increases in $\left[\mathrm{Ca}^{2+}\right]_{\mathrm{i}}, \mathrm{Ca}^{2+}$ efflux and aldosterone secretion elicited by a reduction of $\mathrm{pH}_{\mathrm{o}}$ in the presence of extracellular $\mathrm{Ca}^{2+}$ were abolished in the absence of extracellular $\mathrm{Ca}^{2+}$. The participation of $\mathrm{Ca}^{2+}$ in the actions of $\mathrm{H}^{+}$is consistent with the importance of the divalent cation in the regulation of aldosterone secretion.

Although the present data indicate an important role for $\mathrm{Ca}^{2+}$ in the actions of $\mathrm{H}^{+}$, other ions may contribute to the overall steroidogenic response. Certainly, $\mathrm{Na}^{+}$and $\mathrm{H}^{+}$ fluxes change concurrently with those of $\mathrm{Ca}^{2+}$, and alterations in the intracellular concentrations of $\mathrm{Na}^{+}$and $\mathrm{H}^{+}$may affect aldosterone synthesis through mechanisms that are not directly related to $\left[\mathrm{Ca}^{2+}\right]_{\mathrm{i}}$ or $\mathrm{Ca}^{2+}$ flux across the plasma membrane (Jefcoate \& Boyd 1971, Matsuoka et al. 1984, Rossier et al. 1987). A decrease in $\mathrm{pH}_{\mathrm{i}}$ in glomerulosa cells occurs in response to extracellular acidification, and alterations of $\mathrm{pH}_{\mathrm{i}}$ have been implicated in the stimulation of aldosterone secretion by AngII and $\mathrm{K}^{+}$ (Horiuchi et al. 1989, Conlin et al. 1990, 1993). Similarly, intracellular $\mathrm{Na}^{+}$concentration $\left(\left[\mathrm{Na}^{+}\right]_{\mathrm{i}}\right)$ increases in response to AngII (Van der Bent et al. 1993), and changes in $\left[\mathrm{Na}^{+}\right]_{\mathrm{i}}$ arising from increases in $\mathrm{Na}^{+} / \mathrm{Ca}^{2+}-$ and $\mathrm{Na}^{+} /$ $\mathrm{H}^{+}$-exchange may contribute to the steroidogenic response to $\mathrm{H}^{+}$. A resulting depolarization of the plasma membrane may affect $\left[\mathrm{Ca}^{2+}\right]_{\mathrm{i}}$ through activation of voltage-dependent $\mathrm{Ca}^{2+}$ channels. These and other possibilities are supported by the ability of $\mathrm{pH}$ to influence membrane potential, ion conductances, inositol 1,4,5trisphosphate $\left(\mathrm{IP}_{3}\right)$ - and $\mathrm{Ca}^{2+}$-induced $\mathrm{Ca}^{2+}$ release, and diacylglycerol-induced association of protein kinase $\mathrm{C}$ with plasma membrane in other cell types (Albuquerque \& Leffler 1998, Hulme \& Orchard 1998, Nishino et al. 1998, 


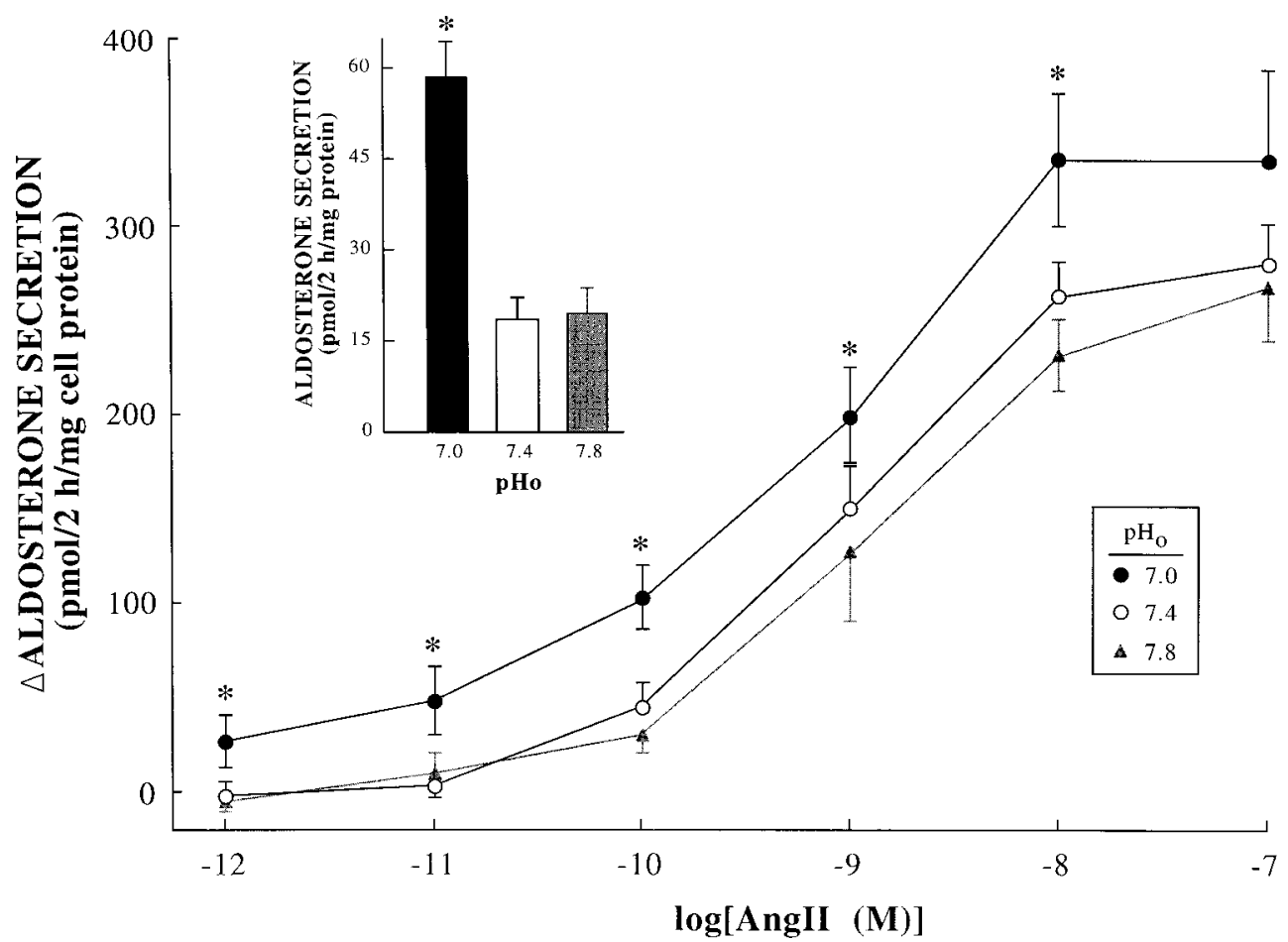

Figure 5 Effects of $\mathrm{pH}_{\mathrm{o}}$ on Angll-stimulated aldosterone secretion. Aldosterone secretion by adherent glomerulosa cells was measured under static conditions at $\mathrm{pH}_{\mathrm{o}} 7 \cdot 8,7 \cdot 4$ or $7 \cdot 0$ in the absence or presence of Angll $\left(1 \times 10^{-12}\right.$ to $\left.1 \times 10^{-7} \mathrm{M}\right)$. The insert depicts aldosterone secretion as a function of $\mathrm{pH}_{\mathrm{o}}$ in the absence of Angll. For each experiment, mean secretory rates of control (i.e. $\mathrm{pH}_{\mathrm{o}}$ only) cells were subtracted from the secretory rate of Angll-treated cells incubated at the same $\mathrm{pH}_{\mathrm{o}}$. Data represent the mean \pm S.E.M. of four independent experiments; in each, rates measured in triplicate cultures were averaged to give a single value. ${ }^{*} P<0.05$ vs the same Angll concentration.

Peng et al. 1998, Wu \& Fry 1998, Kourie 1999). Interrelationships between $\mathrm{Ca}^{2+}, \mathrm{H}^{+}$and $\mathrm{Na}^{+}$fluxes and cytosolic concentrations provide potential means through which $\mathrm{pH}_{\mathrm{o}}$ may independently affect aldosterone secretion. Such interactions may also allow $\mathrm{pH}_{\mathrm{o}}$ to modulate the actions of AngII and $\mathrm{K}^{+}$as well as other factors, notably extracellular osmolality (Schneider \& Kramer 1986, Wang et al. 1992) and $\left[\mathrm{Na}^{+}\right]_{\mathrm{o}}$ (Saruta et al. 1972, Lobo et al. 1978), that influence aldosterone secretion through $\mathrm{Ca}^{2+}$-dependent mechanisms.

Indeed, results of the present studies confirm previous reports (Chiu \& Freer 1978, Radke et al. 1986b, Raff \& Jankowski 1993) that reductions in $\mathrm{pH}_{\mathrm{o}}$ increased AngII-stimulated aldosterone secretion. Some differences, however, in the specific effects of $\mathrm{H}^{+}$are apparent. For example, aldosterone secretion by perfused dog adrenals was directly related to $\left[\mathrm{H}^{+}\right]_{\mathrm{o}}$ over a range of approximately 16 to $70 \mathrm{nM}\left(\mathrm{pH}_{\mathrm{o}} 7 \cdot 8\right.$ to $\left.7 \cdot 16\right)$ (Radke et al. 1986b), whereas aldosterone secretion by cultured bovine glomerulosa cells was not significantly affected at a $\left[\mathrm{H}^{+}\right]_{\mathrm{o}}$ of less than $40 \mathrm{nM}\left(\mathrm{pH}_{\mathrm{o}} 7 \cdot 4\right)$. In rabbit glomerulosa cells, a reduction of $\mathrm{pH}_{\mathrm{o}}$ from $7 \cdot 4$ to 6.5 increased both the sensitivity to AngII and the magnitude of the secretory response (Chiu \& Freer 1978). In the present studies, only the secretory response to AngII was increased, albeit by a smaller reduction of $\mathrm{pH}_{\mathrm{o}}$ (from $7 \cdot 4$ to $7 \cdot 0$ ).

The mechanisms by which $\mathrm{H}^{+}$modulates AngIIstimulated aldosterone secretion are presently unclear, but appear to differ from the means by which it independently increases basal aldosterone secretion. Increased association of AngII with its receptor (Carroll et al. 1986) can not account for the increase in AngII-stimulated aldosterone secretion caused by $\mathrm{H}^{+}$reported here. To the contrary, transduction between AngII receptor binding and generation of a $\mathrm{Ca}^{2+}$ signal was attenuated by $\mathrm{H}^{+}$. This effect may be partially explained by decreased binding of $\mathrm{IP}_{3}$ in adrenocortical microsomes and, consequently, decreased $\mathrm{Ca}^{2+}$ mobilization (Guillemette \& Segui 1988, Rossier et al. 1989). It may be rationalized also by the fact that $\mathrm{H}^{+}$ independently elicited a $\mathrm{Ca}^{2+}$ signal. If it did so through a mechanism common to the action of AngII, the magnitude of the AngII-stimulated $\mathrm{Ca}^{2+}$-signal would be correspondingly decreased. In keeping with a modulatory role for $\mathrm{H}^{+}$, attenuation of the AngII-stimulated $\mathrm{Ca}^{2+}$-signal would be greater at lower concentrations of the peptide than it would be at higher concentrations. This expectation is 


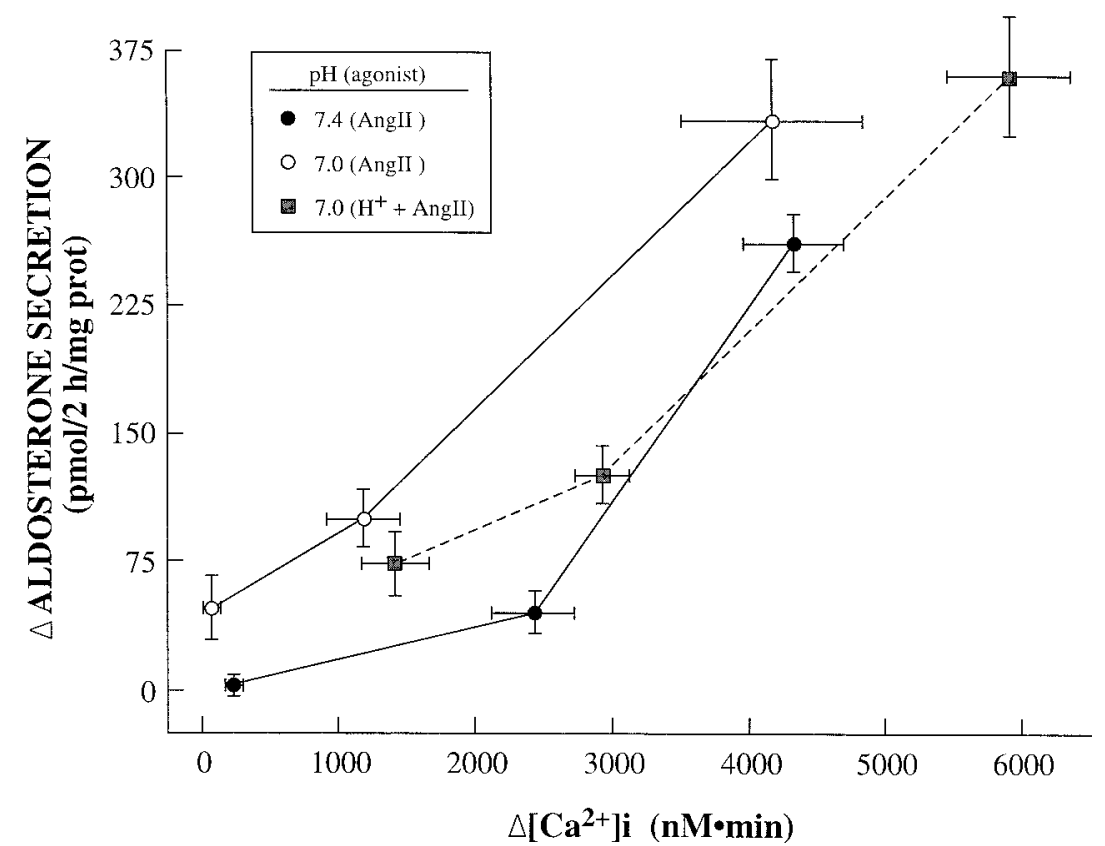

Figure 6 Effect of extracellular acidification on the relationship between Angll-stimulated $\mathrm{Ca}^{2+}$ and secretory responses. Increases in aldosterone secretion and $\left[\mathrm{Ca}^{2+}\right]_{i}$ caused by Angll $\left(1 \times 10^{-11}, 1 \times 10^{-10}\right.$ and $\left.1 \times 10^{-8} \mathrm{M}\right)$ were measured in parallel incubations in medium of $\mathrm{pH}_{0} 7 \cdot 4$ or $7 \cdot 0$. In each instance, responses to Angll were corrected for basal $\left(\mathrm{pH}_{\mathrm{o}} 7 \cdot 4\right.$ or $7 \cdot 0$ without Angll) values and were concentration-dependent. The $\mathrm{Ca}^{2+}$ signal was integrated and is expressed as an AUC. Also, the combined increase in aldosterone secretion caused by $\mathrm{H}^{+}$plus Angll is plotted as a function of the combined integrated $\mathrm{Ca}^{2+}$ response. Data represent the mean \pm S.E.M. for four independent experiments.

consistent with data presented in Fig. 4 as well as an effect of $\mathrm{H}^{+}$to decrease binding of $\mathrm{IP}_{3}$ in adrenocortical microsomes while not affecting maximal $\mathrm{IP}_{3}$-stimulated $\mathrm{Ca}^{2+}$ release over the range of $\mathrm{pH}$ used in the present studies (Guillemette \& Segui 1988). The effect of $\mathrm{H}^{+}$to enhance AngII-stimulated aldosterone secretion in the presence of a reduced AngII-stimulated $\mathrm{Ca}^{2+}$ signal indicates an action of $\mathrm{H}^{+}$distal to $\mathrm{Ca}^{2+}$ mobilization. Given the obligatory role for $\mathrm{Ca}^{2+}$ in AngII-stimulated aldosterone secretion, the present data also suggest that this late action(s) results in a greater $\mathrm{Ca}^{2+}$ sensitivity of a more distal component of the AngII-dependent signaling cascade. In this respect, the transient $\mathrm{Ca}^{2+}$ signal (or another intracellular signal) elicited by $\mathrm{H}^{+}$may partially substitute for the initial 'trigger' $\mathrm{Ca}^{2+}$ mobilized by AngII (Barrett et al. 1989) and contribute to the gain of AngII-stimulated aldosterone secretion. Alternatively, $\mathrm{H}^{+}$may enhance the activation of adenylyl cyclase by AngII (Baukal et al. 1994, Python et al. 1995). Stimulation through separate, but convergent, $\mathrm{Ca}^{2+}-$ and cAMP-dependent pathways could account for the potentiating effect of $\mathrm{H}^{+}$on aldosterone secretion at low concentration of AngII. The present data, however, do not directly address these possibilities.

Although $\mathrm{H}^{+}$increased both basal and AngII-stimulated aldosterone secretion, the site in the steroidogenic pathway at which it acts remains to be identified. It would be expected that an effect of $\mathrm{H}^{+}$to increase aldosterone secretion would be manifested at the level of cholesterol side-chain cleavage or conversion of corticosterone to aldosterone. These reactions limit aldosterone biosynthesis and are subject to regulation by AngII and other primary agonists (McKenna et al. 1978, Aguilera et al. 1980, Kramer et al. 1980). An increase in the activity of either enzyme, or both enzymes, in response to $\mathrm{H}^{+}$would reasonably explain the increases in aldosterone secretion caused by reduction of $\mathrm{pH}_{\mathrm{o}}$. Further, an effect of $\mathrm{H}^{+}$to increase the transfer of cholesterol to mitochondria, with or without a concomitant effect to increase its translocation from the outer to the inner membrane, could account for the greater $\mathrm{Ca}^{2+}$ sensitivity of AngII-stimulated aldosterone secretion. Jefcoate \& Boyd (1971) presented evidence that $\mathrm{H}^{+}$directly stimulated cholesterol side-chain cleavage in isolated bovine adrenocortical mitochondria, and Radke et al. (1986b) suggested that $\mathrm{H}^{+}$increased the conversion of corticosterone to aldosterone by perfused canine adrenals. However, neither the rate of pregnenolone production from endogenous cholesterol nor the rate of aldosterone production from exogenous corticosterone was affected by reduction of $\mathrm{pH}_{\mathrm{o}}$ from $7 \cdot 2$ to $6 \cdot 8$ (Raff \& Jankowski 1993). 
In summary, the present data indicate that $\mathrm{H}^{+}$has direct actions on glomerulosa cells to increase $\left[\mathrm{Ca}^{2+}\right]_{\mathrm{i}}$ and promote aldosterone secretion. In light of these actions, $\mathrm{pH}_{\mathrm{o}}$ participates in the regulation of aldosterone secretion. These actions of $\mathrm{H}^{+}$contribute to changes in plasma aldosterone concentration associated with disturbances in acid-base balance by changing the basal rate of aldosterone secretion as well as by modulating the responses to other secretogogues, notably AngII. Furthermore, in light of results of these and previous studies, it seems reasonable to predict that the actions of $\mathrm{H}^{+}$are themselves subject to modulation; the direction and magnitude of the response being determined by the concentration of primary agonists as well as other factors that modulate aldosterone secretion.

\section{Acknowledgements}

This work was supported by United States Public Health Service grants DK-40253 and DK-33562 and Grants-InAid from the Mississippi and Tennessee Affiliates of the American Heart Association.

\section{References}

Aguilera, G, Menard, RH \& Catt KJ 1980 Regulatory actions of angiotensin II on receptors and steroidogenic enzymes in adrenal glomerulosa cells. Endocrinology 107 55-60.

Albuquerque ML \& Leffler CW $1998 \mathrm{pHo}, \mathrm{pH}_{\mathrm{i}}$ and $\mathrm{pCO}_{2}$ in stimulation of $\mathrm{IP}_{3}$ and $\left[\mathrm{Ca}^{2+}\right]_{c}$ in piglet cerebrovascular smooth muscle. Proceedings of the Society for Experimental Biology and Medicine 219 226-234

Barrett PQ, Bollag WB, Isales CM, McCarthy RT \& Rasmussen H 1989 Role of calcium in angiotensin II-mediated aldosterone secretion. Endocrine Reviews 10 496-518.

Baukal AJ, Hunyady L, Catt KJ \& Balla T 1994 Evidence for participation of calcineurin in potentiation of agonist-stimulated cyclic AMP formation the calcium-stimulating hormone, angiotensin II. Journal of Biological Chemistry $26924546-24549$

Borle AB, Uchikawa T \& Anderson JH 1982 Computer simulation and interpretation of ${ }^{45} \mathrm{Ca}$ efflux profile patterns. Journal of Membrane Biology 68 37-46.

Carroll JE, Landry AS, Elliott ME \& Goodfriend TL 1986 Effects of $\mathrm{pH}$ on adrenal angiotensin receptors and responses. Journal of Laboratory and Clinical Medicine 108 23-29.

Chiu AT \& Freer RJ 1978 Angiotensin-induced steroidogenesis in rabbit adrenal: effects of $\mathrm{pH}$ and calcium. Molecular and Cellular Endocrinology 13 159-166.

Christlieb AR, Assal J, Katsilambros N, Williams GH, Kozak GP \& Suzuki T 1975 Plasma renin activity and blood volume in uncontrolled diabetes: ketoacidosis, a state of secondary aldosteronism. Diabetes 24 190-193.

Conlin PR, Kim SY, Williams GH \& Canessa ML $1990 \mathrm{Na}^{+}-\mathrm{H}^{+}$ exchanger kinetics in adrenal glomerulosa cells and its activation by angiotensin II. Endocrinology 127 236-244.

Conlin PR, Cirillo M, Zerbini G, Williams GH \& Canessa ML 1993 Calcium-mediated intracellular acidification and activation of $\mathrm{Na}^{+}-\mathrm{H}^{+}$exchange in adrenal glomerulosa cells stimulated with potassium. Endocrinology 132 1345-1352.

Gilchrist M, Kem DC \& Washburn D 1983 The effect of acidosis and alkalosis on in vitro aldosterone production. Metabolism 32 697-700.
Grynkiewicz G, Poenie M \& Tsien RY 1985 A new generation of $\mathrm{Ca}^{2+}$ indicators with greatly improved fluorescence properties. Journal of Biological Chemistry 260 3440-3450.

Guillemette G \& Segui JA 1988 Effects of pH, reducing and alkylating reagents on the binding and $\mathrm{Ca}^{2+}$ release activities of inositol 1,4,5-trisphosphate in the bovine adrenal cortex. Molecular Endocrinology 2 1249-1255.

Horiuchi T, Nguyen T-T, Cragoe EJ Jr \& De Lean A 1989 Regulation of aldosterone biosynthesis by $\mathrm{Na}^{+} / \mathrm{H}^{+}$antiport: relationships between intracellular $\mathrm{pH}$ and angiotensin II. Endocrinology 124 1925-1931.

Hulme JT \& Orchard CH 1998 Effects of acidosis on $\mathrm{Ca}^{2+}$ uptake and release by sarcoplasmic reticulum of intact rat ventricular myocytes. American Journal of Physiology: Heart and Regulatory Physiology 275 H977-H987.

Jefcoate CR \& Boyd GS 1971 pH-dependent changes in the spin state of cytochrome P450 from adrenal mitochondria. FEBS Letters 12 279-284.

Jones GV, Wall BM, Williams HH, Presley DN, Sapir DG \& Cooke CR 1992 Modulation of plasma aldosterone by physiological changes in hydrogen ion concentration. American Journal of Physiology: Regulatory, Integrative and Comparative Physiology 262 R269-R275.

Julian BA, Galla JH, Guthrie GP Jr \& Kotchen TA 1982 Renin and aldosterone responses to short-term $\mathrm{NaCl}$ or $\mathrm{NaHCO}_{3}$ loading in man. Journal of Laboratory and Clinical Medicine 100 261-268.

Kassirer JP, Appleton FM, Chazan JA \& Schwartz WB 1967 Aldosterone in metabolic acidosis. Journal of Clinical Research 46 1558-1571.

Kourie JI 1999 pH-modulation of chloride channels from the sarcoplasmic reticulum of skeletal muscle. Journal of Membrane Biology 167 73-83.

Kramer RE 1988a Angiotensin II causes sustained elevations in cytosolic calcium in glomerulosa cells. American Journal of Physiology: Endocrinology and Metabolism 255 E338-E346.

Kramer RE 1988 b Angiotensin II-stimulated changes in calcium metabolism in cultured glomerulosa cells. Molecular and Cellular Endocrinology 60 199-210.

Kramer RE 1991 N-2-Hydroxyethypiperazine-N-2-ethanesulfonic acid (Hepes) does not modify the angiotensin II-stimulated calcium signal in cultured bovine glomerulosa cells. Life Sciences 48 27-35.

Kramer RE, Gallant S \& Brownie AC 1980 Actions of angiotensin II on aldosterone biosynthesis in the rat adrenal cortex: effects on cytochrome P450 enzymes of the early and late pathway. Journal of Biological Chemistry 255 3442-3447.

Lobo MV, Marusic ET \& Aguilera G 1978 Further studies on the relationship between potassium and sodium levels and adrenocortical activity. Endocrinology 102 1061-1068.

Matsuoka H, Ishii M, Yamakado M \& Uehara Y 1984 Effect of natrium ionophore on aldosterone production in the rat adrenal gland. Endocrinology 115 2039-2044.

McKenna, TJ, Island DP, Nicholson WE \& Liddle GH 1978 Angiotensin. Journal of Steroid Biochemistry and Molecular Biology 9 967-972.

Muller J 1965 Aldosterone stimulation in vitro. II. Stimulation of aldosterone production by monovalent cations. Acta Endocrinologica 50 301-309.

Nishino N, Sugimoto I \& Hashimoto E 1998 Possible role of alteration in $\mathrm{pH}$, but not ionic strength, in the modulation of $\mathrm{Ca}^{2+}$-dependent and diacylglycerol-induced association of protein kinase C-alpha with plasma membrane. Biochemistry and Molecular Biology International 46 725-731.

Peng HL, Ivarsen A, Nilsson H \& Aalkjaer C 1998 On the cellular mechanism for the effect of acidosis on vascular tone. Acta Physiologica Scandinavica 164 517-525.

Perez GO, Oster JR, Vaamonde CA \& Katz FH 1977 Effects of $\mathrm{NH}_{4} \mathrm{Cl}$ on plasma aldosterone, cortisol and renin activity in 
supine man. Journal of Clinical Endocrinology and Metabolism 45 $762-767$

Perez GO, Oster JR, Katz FH \& Vaamonde CA 1979 The effect of acute metabolic acidosis on plasma cortisol, renin activity and aldosterone. Hormone Research 11 12-21.

Perez GO, Kem DC, Oster JR \& Vaamonde CA 1980 Effect of acute metabolic acidosis on the renin-aldosterone system. Mechanism of increases in plasma aldosterone in dogs infused with lactic acid. Journal of Laboratory and Clinical Medicine 96 371-378.

Python CP, Laban OP, Rossier MF, Vallotton MB \& Capponi AM 1995 The site of action of $\mathrm{Ca}^{2+}$ in the activation of steroidogenesis: studies in $\mathrm{Ca}^{2+}$-clamped bovine zona-glomerulosa cells. Biochemical Journal 305 569-576.

Quigley C, Sullivan PA, Gonggrijp H, Crowley MJ, Ferriss JB \& O'Sullivan DJ 1982 Hyperaldosteronism in ketoacidosis and in poorly controlled non-ketonic diabetes. Irish Journal of Medical Science 151 135-139.

Radke KJ, Schneider EG, Taylor RE Jr \& Kramer RE 1986 a Effect of hydrogen ion concentration on corticosteroid secretion. American Journal of Physiology: Endocrinology and Metabolism 250 E259-E264.

Radke KJ, Taylor RE Jr \& Schneider EG $1986 b$ Effect of hydrogen ion concentration on aldosterone secretion by isolated perfused canine adrenal glands. Journal of Endocrinology $110292-301$.

Raff $\mathrm{H} \&$ \& Jankowski B 1993 Effect of $\mathrm{CO}_{2} / \mathrm{pH}$ on the aldosterone response to hypoxia in bovine adrenal cells in vitro. American Journal of Physiology: Regulatory, Integrative and Comparative Physiology $26 \mathbf{5}$ R $820-\mathrm{R} 825$.

Raff H \& Roarty TP 1988 Renin, ACTH, and aldosterone during acute hypercapnia and hypoxia in conscious rats. American Journal of Physiology: Regulatory, Integrative and Comparative Physiology 254 R431-R435.

Robinson TV, Wang W, Hayama N, Kramer RE \& Schneider EG 1990 Effects of changing $\mathrm{pH}$ on intracellular calcium and aldosterone secretion. FASEB Journal 4 A543.

Rossier MF, Krause KH, Lew PD, Capponi AM \& Vallotton MB 1987 Control of cytosolic free calcium by intracellular organelles in bovine adrenal glomerulosa cells: effects of sodium and inositol 1,4,5-trisphosphate. Journal of Biological Chemistry 262 4053-4058.

Rossier MF, Capponi AM \& Vallotton MB 1989 The inositol 1,4,5-trisphosphate-binding site in adrenal cortical cells is distinct from the endoplasmic reticulum. Journal of Biological Chemistry 264 14078-14084

Saruta TR, Cook R \& Kaplan NM 1972 Adrenocortical steroidogenesis: studies on the mechanism of action of angiotensin and electrolytes. Journal of Clinical Research 51 2239-2245.

Schambelan M \& Sebastian A 1977 Adrenocortical hormone response to metabolic acidosis in normal man. Clinical Research 25 301A.

Schneider EG \& Kramer RE 1986 Effect of osmolality on angiotensinstimulated aldosterone production by primary cultures of bovine adrenal glomerulosa cells. Biochemical and Biophysical Research Communications 139 46-51.

Scott RS, Espiner EA, Donald RA \& Livesey JH 1978 Hormonal responses during treatment of acute diabetic ketoacidosis with constant insulin infusions. Clinical Endocrinology 9 463-474.

Singer RB \& Hastings AB 1948 An improved clinical method for the estimation of disturbances in the acid-base balance of human blood. Medicine 27 223-242.

Tsien RY, Rink TJ \& Poenie M 1985 Measurement of cytosolic free $\mathrm{Ca}^{2+}$ in individual small cells using fluorescence microscopy with dual excitation wavelengths. Cell Calcium 6 145-157.

Van der Bent V, Demole C, Johnson EIM, Rossier MF, Python CP, Vallotton MB \& Capponi AM 1993 Angiotensin-II induces changes in the cytosolic sodium concentration in bovine adrenal glomerulosa cells: involvement in the activation of aldosterone biosynthesis. Endocrinology 133 1213-1220.

Wang W, Hayama N, Robinson TV, Kramer RE \& Schneider EG 1992 Effect of osmolality on cytosolic free calcium and aldosterone secretion. American Journal of Physiology: Endocrinology and Metabolism 262 E68-E75.

Wu C \& Fry CH 1998 The effects of extracellular and intracellular $\mathrm{pH}$ on intracellular $\mathrm{Ca}^{2+}$ regulation in guinea-pig detrusor smooth muscle. Journal of Physiology 508 131-143.

Yamauchi T, Harada T, Matsumura Y, Sueda K \& Matsui N 1997 Effect of acid-base disturbances on aldosterone in man. Journal of Endocrinological Investigation 20 576-579.

Received 3 December 1999

Revised manuscript received 1 March 2000

Accepted 14 March 2000 